The Fall and Rise of Jerusalem 
This page intentionally left blank. 


\section{The Fall and Rise of Jerusalem}

Judah under Babylonian Rule

Oded Lipschits

Winona Lake, Indiana

EISENBRAUNS 2005 
(c) Copyright 2005 by Eisenbrauns.

All rights reserved.

Printed in the United States of America.

www.eisenbrauns.com

\section{Library of Congress Cataloging-in-Publication Data}

Lipschitz, Oded.

[Yerushalayim ben hurban le-hithadashut. English]

The fall and rise of Jerusalem : Judah under Babylonian rule / by Oded

Lipschits.

p. $\mathrm{cm}$.

Rev. ed. of author's dissertation.

Includes bibliographical references and indexes.

ISBN I-57506-095-7 (hardback : alk. paper)

I. Judaea (Region)-History. 2. Jews-History-Babylonian captivity, 598-5I 5 B.c. 3. Bible. O.T.-Criticism, interpretation, etc.

4. Palestine-Antiquities. I. Title.

DSi I I.J78L57 2005

$933-\mathrm{dc} 22$

The paper used in this publication meets the minimum requirements of the American National Standard for Information Sciences-Permanence of Paper for Printed Library Materials, ANSI Z39.48-I984. @ ${ }^{\mathrm{TM}}$ 
This book is dedicated to the memory of my father

\section{David (Alex) Lipschits}

I am filled with strong longings for that boy of two who was left alone during the Second World War yet found within himself the strength to rise up from the ruins of his family and nation; to build a family; and to be a father, teacher, and educator.

His life is a genuine saga of Falling and Rising.

So then, yours is truly a journey through memory! . . . It was to slough off a burden of nostalgia that you went so far away!

- Italo Calvino, Invisible Cities (translated by William Weaver; Orlando: Harcourt, I974; Italian original: Le città invisibili, 1972) 98 
This page intentionally left blank. 